\title{
Rancang Bangun Marketplace Pemesanan Jasa Dokumentasi Foto dan Video Pernikahan Berbasis Web
}

\author{
Web Based Marketplace Engineering for Ordering Wedding Photo and Video
} Documentary Service

\author{
I Putu Wira Cahaya Pratama Yudha ${ }^{1}$, I Made Agus Dwi Suarjaya ${ }^{2}$, I Made Sunia Raharja ${ }^{3}$ \\ 1,2,3Program Studi Teknologi Informasi, Fakultas Teknik, Universitas Udayana \\ E-mail: ${ }^{1}$ wiracahaya0251@gmail.com, ${ }^{2}$ agussuarjaya@it.unud.ac.id, ${ }^{3}$ sunia.raharja@ gmail.com
}

\begin{abstract}
Abstrak
Momen pernikahan menjadi momen yang langka bagi pasangan pengantin dan keluarganya sehingga dokumentasi foto maupun video cukup penting untuk mengabadikan momen. Fenomena prewedding yaitu prosesi dokumentasi kemesraan calon pengantin dalam masa persiapan pernikahan (pra-pernikahan) sudah ditemui dan populer sejak tahun 2000-an. Pelaku usaha penyedia jasa dokumentasi pernikahan maupun prewedding khususnya di Bali sudah semakin menjamur. Masalah yang terjadi dari pihak pengguna jasa yaitu minimnya informasi ketika mencari jasa yang sesuai sehingga pengguna jasa memerlukan waktu dan tenaga yang kurang efektif. Sedangkan pihak penyedia jasa memiliki masalah dari sisi pemasaran yang kurang bisa mencangkup pasar yang luas dan penyaluran informasi spesifikasi jasa yang diberikan yang kurang baik. Salah satu solusi yang dapat dilakukan adalah pengimplementasian sistem marketplace pemesanan jasa dokumentasi pernikahan berbasis web. Sistem ini menjadi wadah atau media bertemunya para pengguna jasa dan penyedia jasa. Terdapat dua baru yaitu manajemen jadwal kerja dan mengelola hasil dokumentasi. Berdasarkan hasil kuesioner terhadap 50 orang menghasilkan persentase rata-rata pengujian pada aspek antar muka sistem yang menjawab sangat setuju sebanyak $37 \%$, setuju sebanyak $52 \%$, dan netral sebanyak $11 \%$ serta pada aspek kinerja proses dan fitur sistem menghasilkan persentase rata-rata jawaban sangat setuju sebanyak $43 \%$, setuju sebanyak $48 \%$, dan netral sebanyak $9 \%$.
\end{abstract}

Kata kunci: Marketplace, Web, Dokumentasi, Pernikahan

\begin{abstract}
Wedding moments become rare moment for the couple and their families than the photo and video documentation is important to save the moments. Moreover the phenomenon of prewedding also know as procession of the couple's intimacy documentation in the period of wedding preparation has been encountered and popular since 2000s. There are more wedding and prewedding documentary entrepreneurs in Bali. User's problems is lack of information when they looking for services, so they need more time and energy to find as needed service. Meanwhile, entrepreneur's problem is less extensive marketing and less effective distribution of service information. One of solution can fix this problems is implementing a web based marketplace system for ordering wedding documentation services. This system will be a place for entrepreneurs and users to meet and make transactions. There are two new ones fiturs, wich is work schedule management and photo and video management. Base on the resulted of a questionnaire from 20 respondents, on the interface aspect of the system resulted in an assessment of $37 \%$ strongly agree, 52\% agree and 11\% neutral. And on the process performance and system features aspect resulted in an assessment of 43\% strongly agree, $48 \%$ agree and $9 \%$ neutral.
\end{abstract}

Keywords: Marketplace, Web, Documentation, Wedding 


\section{PENDAHULUAN}

Pernikahan bukanlah sekedar peristiwa atau momen religious-yuridis semata, namun lebih dari itu dimana pernikahan bermakna bertemunya dua orang dan keluarganya yang memiliki latar belakang suku bangsa yang berbeda [1]. Prosesi pernikahan di Indonesia umumnya mengadakan suatu pesta pernikahan rangkaian upacara pernikahan yang berbedabeda dan unik di setiap daerahnya. Peristiwa atau momen pernikahan menjadi salah satu momen langka dan berkesan bagi pasangan pengantin maupun dari keluarga, sehingga dokumentasi berupa foto maupun video merupakan kebutuhan yang cukup penting untuk dipersiapkan dalam acara pernikahan untuk mengabadikan momen.

Selain dokumentasi pada saat acara pernikahan, fenomena prewedding merupakan bagian dari gaya hidup yang lazim ditemui sejak tahun 2000-an [2]. Dokumentasi prewedding merupakan dokumentasi berupa foto maupun video kemesraan calon pengantin dalam masa persiapan pernikahan (pra-pernikahan). Dokumentasi prewedding ini merekam suasana romantisme yang terpancar dari ekspresi dan gesture tubuh yang terbalut busana yang indah pasangan pengantin [3]. Umumnya dokumentasi prewedding dilakukan pada tempat-tempat yang memiliki arsitektur bangunan yang unik atau pemandangan alam yang indah.

Pelaku usaha sebagai penyedia jasa dokumentasi pernikahan maupun prewedding khususnya di Provinsi Bali sudah semakin menjamur. Hal tersebut dikarenakan salah satunya yaitu Bali banyak memiliki tempat-tempat wisata yang kini di komersilkan untuk dijadikan lokasi dokumentasi prewedding. Berdasarkan hasil wawancara yang dilakukan kepada beberapa calon pengantin sebagai pengguna jasa dan pelaku usaha dokumentasi sebagai penyedia jasa terjadi beberapa masalah dalam proses jual beli jasa dokumentasi. Salah satu permasalahan yang umum dikeluhkan oleh pihak pengguna jasa yaitu ketika mencari penyedia jasa dokumentasi hanya mendapat sumber informasi dari mulut ke mulut, sosial media atau pamflet-pamflet iklan di pinggir jalan. Hal tersebut mengakibatkan calon pengguna jasa memerlukan waktu dan tenaga yang kurang efektif untuk mencari jasa dokumentasi yang sesuai. Sedangkan, dari sisi penyedia jasa juga memiliki permasalahan yaitu pemasaran yang kurang bisa mencangkup pasar yang luas, sehingga menjadi suatu masalah untuk mencari pelanggan baru. Penyaluran informasi spesifikasi jasa seperti harga, service yang diberikan masih belum dilakukan dengan baik dikarenakan media pemasaran yang digunakan masih terbatas. Hal ini menjadikan pengusaha-pengusaha jasa dokumentasi khususnya yang baru terjun dibidang tersebut perkembangannya menjadi terhambat.

Berdasarkan permasalahan yang telah diuraikan, secara garis besar pengguna maupun penyedia jasa memiliki permasalahan saat proses jual beli jasa dokumentasi dan penyampaian informasi yang kurang efektif. Belum adanya media atau wadah bagi para pengguna maupun penyedia jasa sebagai titik temu dalam proses jual beli jasa dokumentasi. Salah satu solusi untuk memecahkan masalah tersebut yaitu membangun sistem marketplace berbasis website yang khusus menjual belikan jasa dokumentasi pernikahan. Berdasarkan solusi tersebut dibangunlah sebuah sistem marketplace pemesanan jasa dokumentasi foto dan video berbasis web yang menghimpun pelaku-pelaku usaha yang memiliki jasa dokumentasi untuk mempromosikan dan menjual jasa pada sistem. Selain itu pengguna jasa juga memiliki media untuk mencari jasa yang tepat dengan waktu yang efektif.

Penelitian yang terkait dengan penggunaan marketplace sebagai media berbelanja daring yaitu konsumen memiliki tiga faktor yang mempengaruhi sikap konsumen untuk berbelanja dari melalui marketplace yaitu manfaat yang dirasakan, kualitas website, dan kepercayaan daring. Ketiga hal tersebut berpengaruh positif signifikan pada sikap terhadap berbelanja daring [4]. Penelitian lainnya yaitu pengaruh review dan rating terhadap kepercayaan dan minat customer untuk berbelanja online menunjukan bahwa pada marketplace, review (ulasan) dan rating (penilaian) berpengaruh langsung terhadap minat pembelian meskipun tidak melalui kepercayaan terlebih dahulu. Review sebagai sumber informasi yang dapat memengaruhi pelanggan untuk membeli atau tidak, sedangkan rating dinilai dari kemudahannya karena menggunakan symbol sehingga dapat meningkatkan efektifitas [5]. Penelitian lainnya 
yaitu upaya mempersingkat distribusi penjualan hasil pertanian memberikan dampak positif bagi petani langsung dan kepada konsumen (end user). Rantai distribusi yang melibatkan pihak seperti agen, grosir dan pedagang ecer dapat dipangkas. Sehingga petani mendapat keuntungan lebih besar dan konsumen (end user) mendapat harga yang lebih murah [6]. Penelitian lainnya yaitu perancangan sistem informasi pemesanan $W O$ dikota Padang. Sistem informasi yang memiliki Admin yang berperan langsung dalam pengelolaan sistem dan delapan entitas lainnya. Delapan entitas tersebut yaitu viewer, customer, WO, pelaminan, catering, dokumentasi, hiburan dan $M C$. Pihak catering, $M C$, dan penyedia jasa lainnya menawarkan paket yang dimiliki disemua kategori masing-masing. Customer dapat memesan jasa tersebut dan memberikan testimoni terhadap apa yang dipesan dan pelayanan dari sistem itu sendiri [7]. Penelitian lainnya yaitu penerapan sistem informasi e-marketplace kepada pelaku bisnis original clothing mampu memberikan kemudahan kepada pemilik bisnis untuk memasarkan produknya serta memberikan kemudahan juga untuk para pembeli untuk membeli produk yang asli dan menghindari tindak penipuan [8]. Penelitian mengenai aplikasi marketplace berbasis web untuk penyedia jasa les private dikota Pontianak memungkinkan untuk para guru mempromosikan dirinya sendiri untuk bersedia mengajar les private dan mengisi seluruh data diri, prestasi, kompetensi, dan track record-nya pada sistem. Aplikasi ini juga menyediakan fitur penjadwalan bagi guru les private. Sehingga para pencari guru les private dapat mengetahui waktu para guru les private siap untuk mengajar. Selain itu berdasarkan hasil kuesioner menggunakan skala Likert's Summated Rating (LSR) diperoleh nilai total 2228 yang terbilang sangat baik dalam mengimplementasikan aplikasi ini [9].

Berdasarkan penelitian-penelitian tersebut maka dibangunlah sistem marketplace berbasis web sebagai media pemesanan jasa dokumentasi pernikahan. Sistem marketplace yang dibangun menggabungkan fitur-fitur, bisnis proses, dan hasil positif yang dibahas pada penelitian-penelitian sebelumnya. Sistem marketplace ini dibangun dengan tambahan dua fitur yang baru dan unik yaitu manajemen jadwal kerja pada sistem bagi pihak penyedia jasa dan menyediakan fitur untuk mengunggah hasil dokumentasi oleh pihak penyedia jasa dan mengunduh hasil dokumentasi secara langsung pada website oleh pihak pengguna jasa.

\section{METODE PENELITIAN}

Metode penelitian pada Rancang Bangun Marketplace Pemesanan Jasa Dokumentasi Foto dan Video Pernikahan Berbasis Web meliputi alur penelitian, metode pengembangan sistem, model pengembangan Extreme Programming, gambaran umum sistem, dan diagram konteks.

\subsection{Alur Penelitian}

Alur penelitian pada Rancang Bangun Marketplace Pemesanan Jasa Dokumentasi Foto dan Video Pernikahan Berbasis Web dapat dilihat pada Gambar 1. 


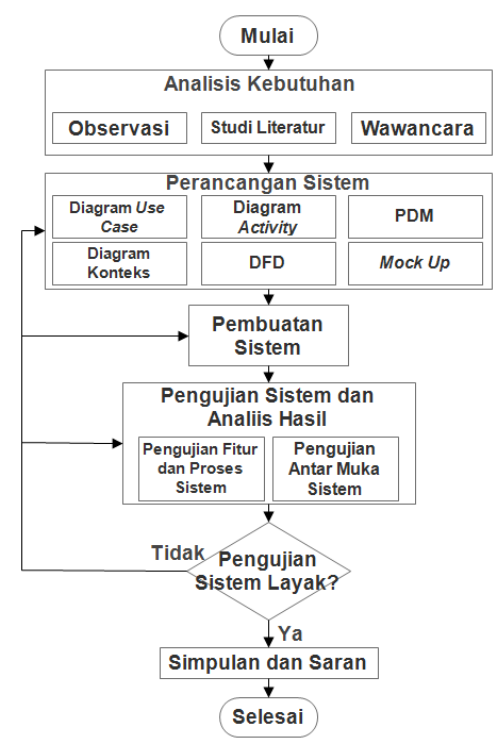

Gambar 1 Alur Penelitian

Gambar 1 merupakan gambaran alur penelitian yang memiliki lima proses. Proses pertama yaitu proses analisis kebutuhan yaitu proses pencarian segala data dan informasi yang dibutuhkan dengan melakukan tiga kegiatan. Observasi dilakukan pada pelaku usaha dokumentasi pernikahan guna mengetahui model-model proses bisnis yang diimplementasikan. Studi literatur yaitu mencari data dan informasi pada jurnal-jurnal penelitian terdahulu dan buku-buku yang berkaitan dengan penelitian. Wawancara dilakukan kepada para penyedia jasa dan pengguna jasa guna mengetahui permasalahan-permasalahan yang masih ada dilapangan. Proses yang kedua yaitu perancangan sistem yaitu membuat pemodelan sistem dengan merancang diagram use case, diagram activity, physical data model, diagram konteks, DFD dan desain tampilan sementara website. Proses ketiga yaitu pembuatan sistem atau memulai untuk melakukan pemrograman website. Proses keempat yaitu pengujian sistem yang melakukan dua buah pengujian yaitu pengujian antar muka dan pengujian proses dan fitur sistem serta melakukan analisa hasil dari dua buah pengujian pengujian. Jika pada pengujian sistem mendapatkan hasil yang layak atau sistem berjalan dengan semestinya maka dilanjutkan pada proses yang kelima yaitu pengambilan kesimpulan. Namun jika pengujian sistem menghasilkan hasil yang tidak layak atau tidak berjalan dengan semestinya maka tahapan diulang kembali kepada proses yang dirasa dapat memecahkan masalah.

\subsection{Metode Pengembangan Sistem}

Metode pengembangan pada penelitian ini menggunakan metode Agile. Metode pengembangan sistem Agile merupakan metode yang memiliki beberapa jenis yang berbasis pada model pengembangan iteratif (perulangan) [10]. Kata Agile yang dapat bermakna cepat, ringan, bebas bergerak juga bisa mengartikan bahwa metode pengembangan Agile merupakan metode pengembangan sistem jangka pendek, memiliki respon yang cepat akan perubahan pada saat proses pengembangan. Agile memiliki beberapa jenis model pengembangan diantaranya yaitu Extreme Programming, Adaptive Software Development, Dynamic Systems Development Method, Scrum Methodology, Crystal, Feature Driven Development dan Agile Modeling.

\subsection{Model Extrem Progamming (XP)}

Berdasarkan metode pengembangan sistem yang digunakan pada penelitian ini, dipilih jenis pengembangan Extreme Programming (XP) untuk diimplementasikan pada proses pengembangan sistem. Pengimplementasian model Extreme Programming pada penelitian ini dikarenakan model XP umumnya digunakan pada jumlah tim yang kecil sampai menengah, dan ditujukan pada kualitas sistem dan adaptif terhadap perubahan berdasarkan kebutuhan 
pengguna.

Model Extreme Programming mulai dipublikasikan oleh Kent Beck pada tahun 1999 yang menggunakan pendekatan berorientasi objek [10]. Karena model ini adalah salah satu jenis atau bagian dari metode pengembangan Agile sehingga model pengembangan jenis ini berbasis iterasi atau perulangan.

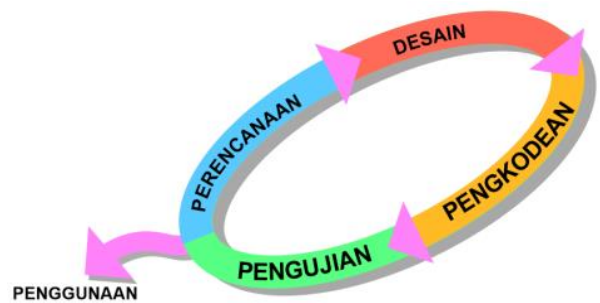

Gambar 2 Alur Kehidupan Model Extreme Programming

Gambar 2 menampilkan beberapa tahapan dalam pengembangan sistem menggunakan model Extreme Programming. Model ini memiliki beberapa tahap yaitu perencanaan, desain, pengkodean, dan pengujian. Tahap perencanaan yaitu tahap yang melakukan pengumpulan informasi tentang kebutuhan sistem dari pihak pengguna sistem. Tahap desain yaitu tahapan yang membuat desain sistem seperti desain basis data, DFD, use case diagram, desain tampilan dan lainnya. Tahap pengkodean yaitu tahapan yang membuat kode program sesuai yang direncanakan dan didesain. Serta tahap pengujian yaitu tahapan yang melakukan pengujian terhadap sistem untuk mengetahui apakah sistem sudah berjalan dengan baik atau belum. Jika sudah berjalan dengan baik maka sistem siap untuk digunakan.

\subsection{Gambaran Umum Sistem}

Gambaran umum sistem pada Racang Bangun Marketplace Pemesanan Jasa Dokumentasi Foto dan Video Pernikahan Berbasis Web dapat dilihat pada Gambar 3.

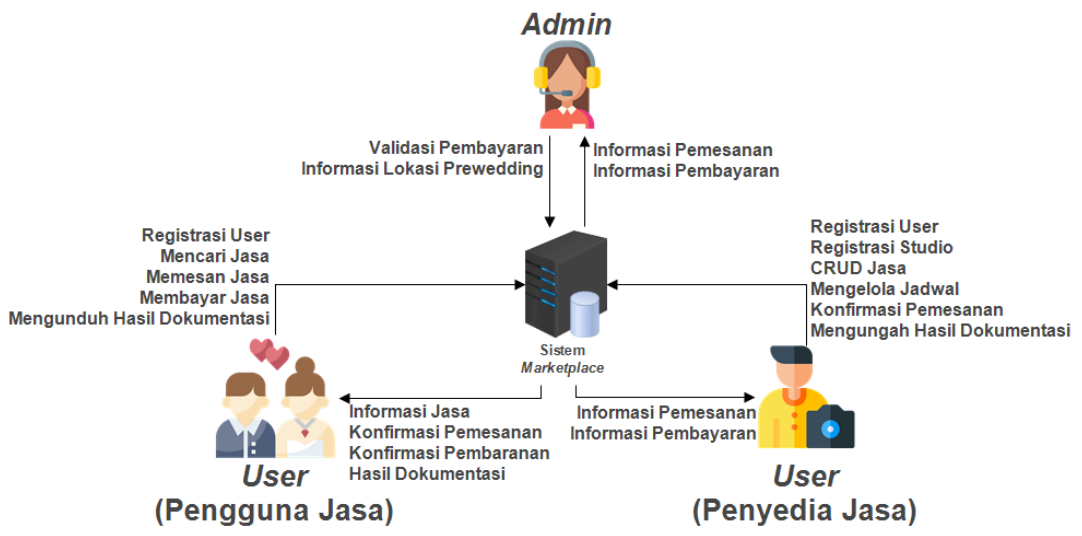

Gambar 3 Gambaran Umum Sistem

Gambar 3 merupakan gambaran umum proses bisnis yang terjadi pada sistem marketplace secara garis besar. Entitas yang terlibat pada sistem terdiri dari tiga yaitu Admin sebagai administrator sistem, User sebagai pengguna jasa, dan User sebagai penyedia jasa. User sebagai penyedia jasa merupakan user yang sama dengan User sebagai pengguna jasa namun yang membedakan adalah User sebagai penyedia jasa memiliki studio (usaha dokumentasi) atau telah mendaftarkan studio pada sistem. Jadi User sebagai penyedia jasa juga dapat menjadi User sebagai pengguna jasa.

\subsection{Diagram Konteks}

Rancang bangun marketplace pemesanan dokumentasi pernikahan ini menggunakan pemodelan dengan diagram konteks yang berfungsi untuk menggambarkan bisnis proses yang 
digunakan dalam sistem. Berikut merupakan diagram konteks dapat dilihat pada Gambar 4.

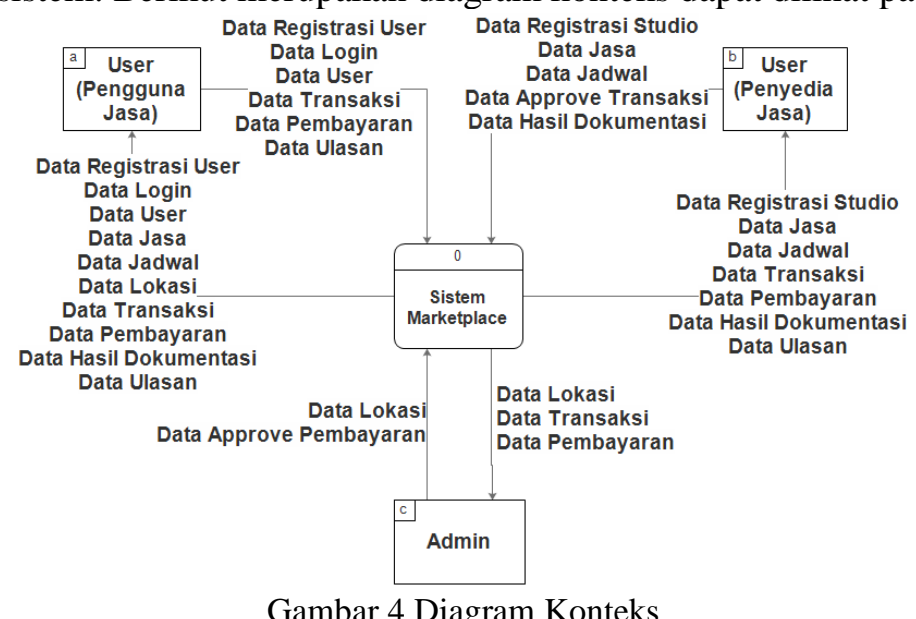

Gambar 4 menunjukan diagram konteks yang terdiri dari tiga buah entitas yang saling terkait satu dengan yang lainnya dalam proses manajemen data yang berpusat pada sistem marketplace. Namun pada dasarnya hanya terdapat dua entitas, yaitu User dan Admin. User (pengguna jasa) merupakan user yang sama dengan User (penyedia jasa) namun yang menjadi pembeda User (penyedia jasa) merupakan user yang memiliki studio atau usaha dokumentasi yang telah di daftarkan pada sistem.

\section{HASIL DAN PEMBAHASAN}

Hasil dan pembahasan terdiri dari hasil implementasi terhadap dua fitur baru dan pengujian sistem terkait tingkat kepuasan pengguna setelah diimplementasikannya sistem marketplace dalam penyelesaian masalah yang sudah disebutkan pada Pendahuluan.

\subsection{Hasil Implementasi}

Hasil implementasi memaparkan 2 fitur tambahan yang sudah disebutkan pada Pendahuluan yang menjadi fitur baru dan unik pada sistem ini yaitu fitur mengelola hasil dokumentasi bagi pengguna dan penyedia jasa serta fitur manajemen jadwal kerja bagi pihak penyedia jasa.

1. Fitur Pengelolaan Hasil Dokumentasi

Fitur pengelolaan hasil dokumentasi merupakan fitur yang memungkinkan penyedia jasa dapat mengunggah hasil dokumentasi dan memungkinkan juga bagi pengguna jasa mengunduh hasil dokumentasinya pada sistem. Selain dapat mengunggah dan mengunduh hasil dokumentasi, fitur ini juga dapat dijadikan media negosiasi terhadap hasil dokumentasi, apakah hasil dokumentasi sudah sesuai dengan keinginan pengguna atau belum. Jika menurut pengguna belum memenuhi keinginan, pihak penyedia jasa dapat menghapus dan mengunggah ulang hasil dokumentasi. Berikut merupakan tab yang dapat diakses oleh penyedia jasa untuk dapat mengunggah dan menyimpan hasil dokumentasi pada Gambar 5. 


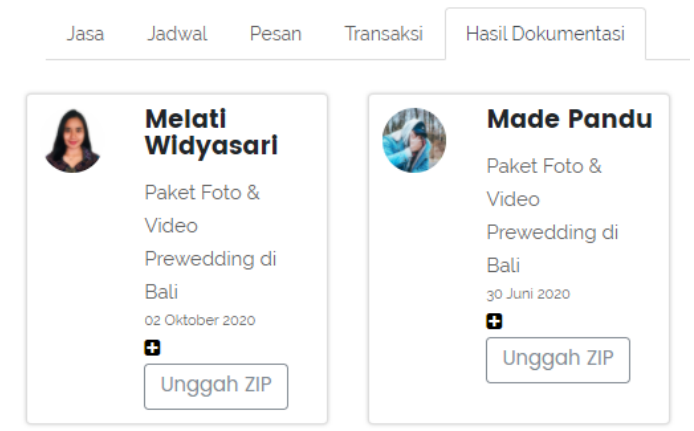

Gambar 5 Tab Hasil Dokumentasi dari Sisi Penyedia Jasa

Gambar 5 menampilkan dua buah folder yang berfungsi sebagai tempat menyimpan hasil dokumentasi. Setiap folder terdapat informasi tentang nama pengguna jasa, jasa yang digunakan, dan tanggal jasa tersebut dilakukan, jadi hasil dokumentasi yang diunggah dan disimpan sesuai dengan informasi yang terdapat di setiap folder tersebut. Tombol Plus (+) digunakan untuk mengunggah atau mengisi folder dengan hasil dokumentasi berupa foto maupun vidio. Sedangkan tombol Unggah ZIP digunakan ketika hasil dokumentasi sudah sesuai dengan keinginan pengguna, pihak penyedia jasa mengunggah file berupa ZIP yang berisi kumpulan foto dan vidio agar pengguna jasa saat mengunduh hasil dokumentasi hanya dengan mengunduh satu file saja. Berikut ketika tombol plus (+) pada salah satu folder digunakan oleh penyedia jasa untuk mengunggah beberapa hasil dokumentasi ditambilkan pada Gambar 6 .

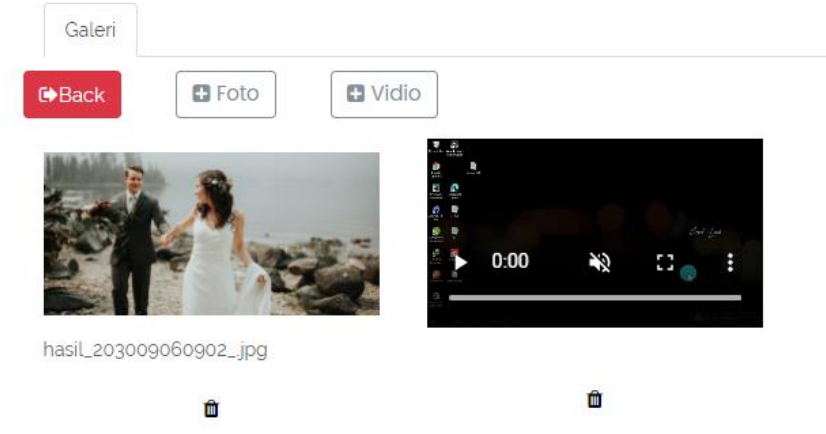

Gambar 6 Unggah Hasil Dokumentasi

Gambar 6 menampilkan dua buah hasil dokumentasi berupa foto dan vidio yang tersimpan di salah satu folder pada Gambar 5. Tombol plus (+) Foto digunakan untuk mengunggah file berupa foto, sedangkan tombol plus (+) Vidio digunakan untuk mengunggah file berupa vidio. Tombol hapus juga sudah disediakan ketika penyedia jasa ingin menghapus salah satu file hasil dokumentasi.

Setelah hasil dokumentasi diunggah oleh pihak penyedia jasa, barulah pihak pengguna jasa dapat melihat dan mengunduh hasil dokumentasi pada sistem. Berikut merupakan $t a b$ yang dapat diakses oleh pengguna jasa yang berguna untuk menyimpan hasil dokumentasi ditampilkan pada Gambar 7. 


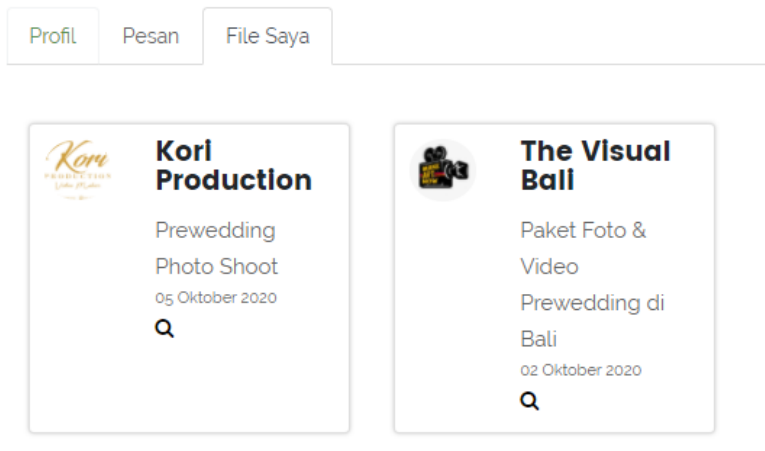

Gambar 7 Tab File Saya

Gambar 7 menampilkan dua buah folder yang berfungsi untuk menyimpan file hasil dokumentasi. Setiap folder memiliki informasi berupa nama Studio atau pihak penyedia jasa, jasa yang digunakan dan tanggal jasa tersebut dilakukan, jadi isi dari setiap folder dikelompokkan berdasarkan informasi tersebut. Tombol kaca pembesar digunakan untuk melihat isi folder, berikut merupakan tampilan ketika tombol tersebut di klik dari salah satu folder, yang ditampilkan pada Gambar 8.

\section{Unduh Semua}
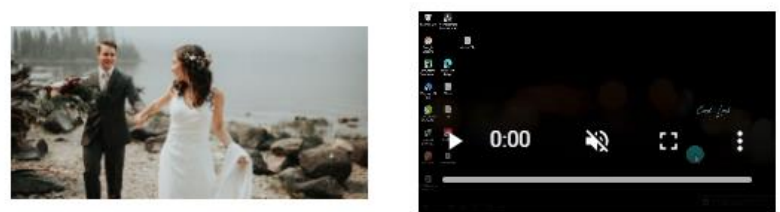

hasil_203009060902_.jpg

\section{Gambar 8 Hasil Dokumentasi Pihak Pengguna Jasa}

Gambar 8 menampilkan hasil dokumentasi berupa foto dan vidio yang tersimpan pada salah satu folder yang terlihat pada Gambar 7. Pada halaman ini pengguna jasa dapat melihat hasil dokumentasi yang sudah diunggah oleh pihak penyedia jasa, sekaligus menjadi media negosiasi apakah hasil dokumentasi sudah sesuai atau belum. Selain itu pada halaman ini tersedia tombol Unduh Semua yang digunakan pihak pengguna jasa mengunduh semua hasil dokumentasi dengan sekaligus yang berupa file ZIP yang diunggah sebelumnya oleh pihak penyedia jasa.

\section{Fitur Pengelolaan Jadwal Kerja}

Fitur pengelolaan jadwal kerja merupakan fitur yang disediakan untuk para penyedia untuk mengelola atau mengatur jadwal kerja mereka masing-masing. Pada fitur ini terdiri dari dua jenis jadwal yaitu jadwal online dan jadwal offline. Jadwal online merupakan jadwal berupa kalender pada sistem, yang dimana setiap jadwal kerjanya terisi secara otomatis ketika pesanan jasa pada sistem telah dibayar oleh pihak pengguna jasa. Sedangkan jadwal offline merupakan jadwal pekerjaan yang dimiliki pihak penyedia jasa berdasarkan pesanan yang masuk secara offline, jadi pihak penyedia jasa mengatur secara manual dengan memasukan tanggal-tanggal yang tidak tersedia untuk menerima pesanan secara online. Berikut merupakan jadwal online yang dimiliki oleh pihak penyedia jasa terlihat pada Gambar 9. 


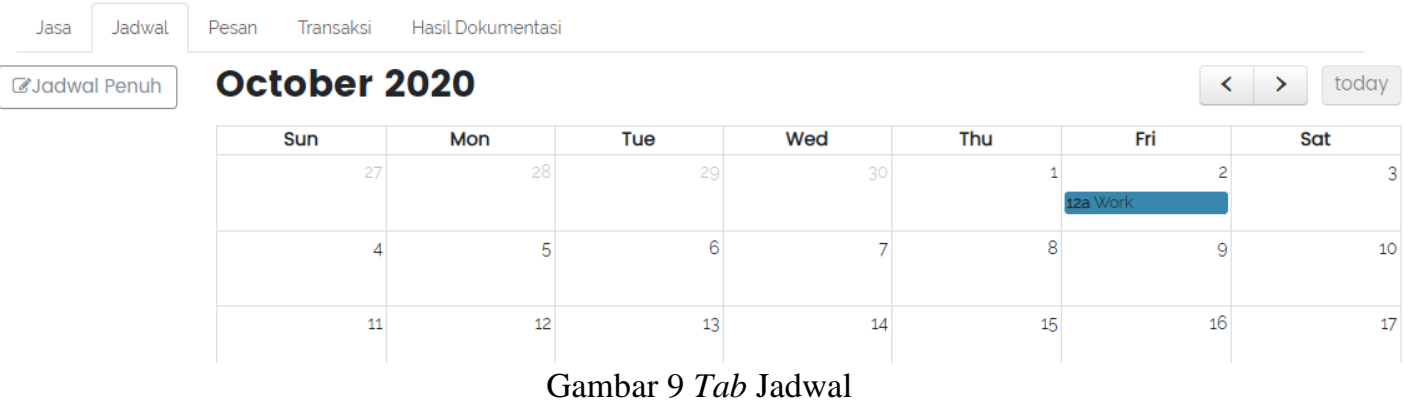

Gambar 9 menamilkan antar muka berupa kalender yang berguna untuk menyimpan jadwal kerja yang masuk secara otomatis ketika sebuah jasa dipesan melalui sistem dan sudah dibayar. Pada Gambar 9 juga menampilkan contoh, pada hari Jumat tanggal 2 Oktober sudah terisi jadwal kerja secara otomatis oleh sistem yang dapat diketahui detail jadwalnya. Berikut tampilan detail jadwal ketika jadwal tersebut di klik terlihat pada Gambar 10.

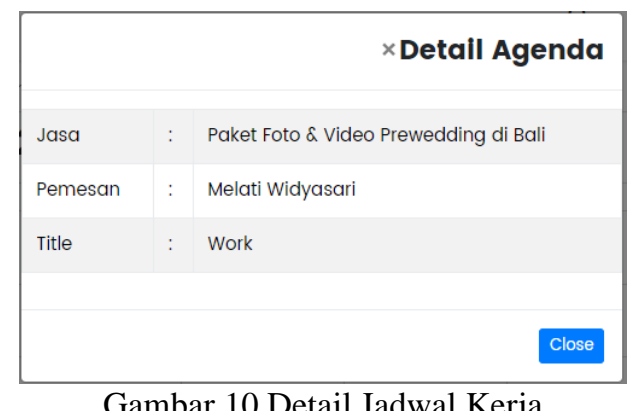

Gambar 10 Detail Jadwal Kerja

Gambar 10 menampilkan detail jadwal dari jadwal yang telah disebutkan pada Gambar 9. Detail jadwal memberikan informasi berupa jasa yang telah dipesan dan nama pihak pengguna jasa.

Sedagkan jadwal offline yang telah dijelaskan sebelumnya berguna ketika pihak penyedia jasa memutuskan pada tanggal-tanggal tertentu tidak dapat melayani pesanan secara online lagi disinilah pihak penyedia jasa dapat menggunakan tombol Jadwal Penuh yang ditampilkan pada Gambar 9. Ketika tombol tersebut di klik maka tampil jendela seperti yang ditampilkan pada Gambar 11.

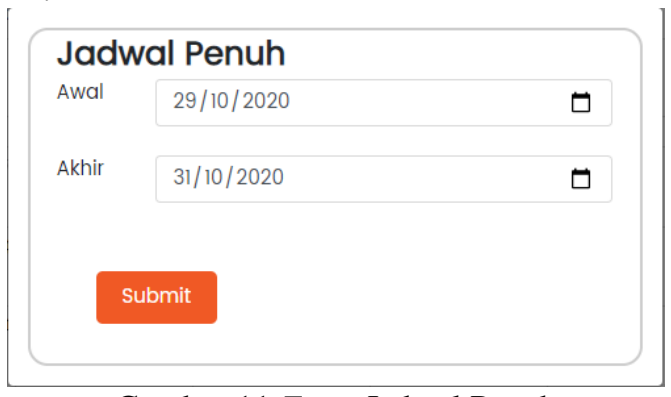

Gambar 11 Form Jadwal Penuh

Gambar 11 menampilkan form untuk memasukan tanggal awal dan akhir yang dimana ditentukan oleh pihak penyedia jasa ketika sudah tidak dapat menerima pesanan melawati sistem. Informasi tersebut berguna bagi calon pengguna jasa untuk mengetahui ketersediaan jadwal ketika hendak memesan jasanya yang ditampilkan pada Gambar 12. 

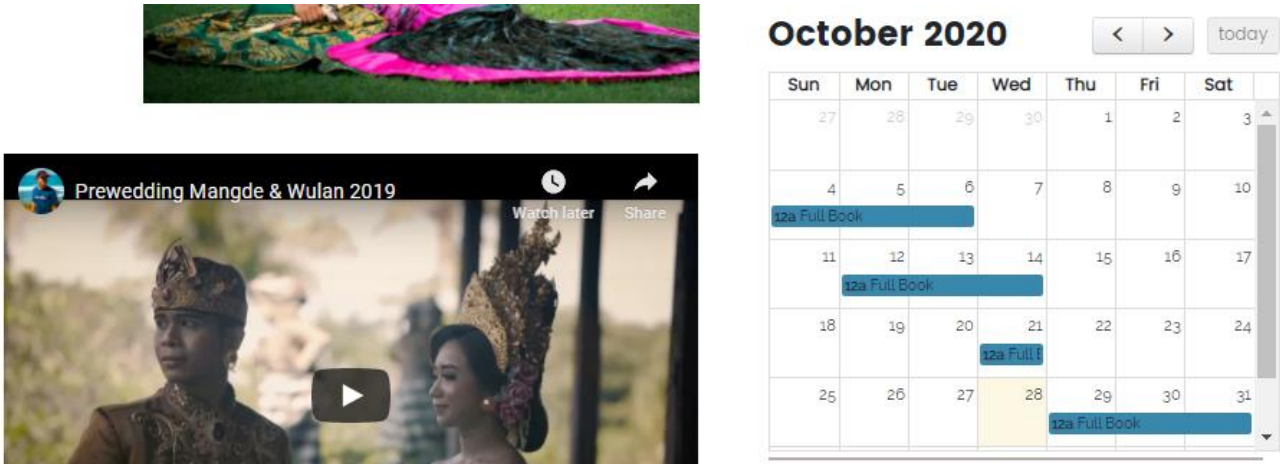

Gambar 12 Tampilan Jadwal Pada Detail Jasa

Gambar 12 menampilkan tanggal-tanggal dari pihak penyedia jasa ketika tidak dapat menerima pesanan lagi melalui sistem yang terlihat pada setiap detail jasa dengan memberikan label Full Book. Informasi ini berguna bagi calon pengguna jasa untuk melakukan perencanaan tanggal dilakukannya proses dokumentasi pernikahan.

\subsection{Analisa Hasil Pengujian Sistem}

Analisa hasil pengujian sistem dilakukan bertujuan untuk mengetahui tingkat kepuasan pengguna setelah implementasi terkait pemecahan masalah yang telah disebutkan pada Pendahuluan. Selain itu pengujian sistem juga bertujuan khususnya untuk mengetahui tingkat kemanfaatan dari dua (2) fitur baru yang tersedia yaitu fitur pengelolaan hasil dokumentasi dan jadwal kerja.

Pengujian sistem dilakukan dengan cara menghitung nilai kuesioner dimana pada kuisioner terdapat beberapa variable pengujian mengenai keseuaian proses dan kelancaran jalannya sistem. Pengisian kuesioner dilakukan oleh 50 orang responden dengan subjek dalam pengujian sistem ditujukan kepada User sebagai pengguna jasa dan User sebagai penyedia jasa (pihak studio). Pengujian dilakukan pada dua aspek yaitu pengujian tampilan antar muka, dan kinerja proses dan fitur sistem. Tabel 1 merupakan hasil uji coba terhadap tampilan antar muka sistem.

Tabel 1 Analisa Hasil Pengujian Tampilan Antar Muka Sistem

\begin{tabular}{|c|l|c|c|c|c|c|c|}
\hline \multirow{2}{*}{ NO } & \multicolumn{1}{|c|}{ Variabel Pengujian } & $\begin{array}{c}\text { Sangat } \\
\text { Setuju }\end{array}$ & Setuju & Netral & $\begin{array}{c}\text { Tidak } \\
\text { Setuju }\end{array}$ & $\begin{array}{c}\text { Sangat } \\
\text { Tidak } \\
\text { Setuju }\end{array}$ & $\begin{array}{c}\text { Jumlah } \\
\text { Responden }\end{array}$ \\
\hline 1 & Tampilan sistem terlihat menarik & $\begin{array}{c}16 \\
(32 \%)\end{array}$ & $\begin{array}{c}31 \\
(62 \%)\end{array}$ & $\begin{array}{c}3 \\
(6 \%)\end{array}$ & $\begin{array}{c}0 \\
(0 \%)\end{array}$ & $\begin{array}{c}0 \\
(0 \%)\end{array}$ & 50 \\
\hline 2 & $\begin{array}{l}\text { Warna yang digunakan pada sistem } \\
\text { nyaman untuk dilihat }\end{array}$ & $\begin{array}{c}25 \\
(50 \%)\end{array}$ & $\begin{array}{c}20 \\
(40 \%)\end{array}$ & $\begin{array}{c}5 \\
(10 \%)\end{array}$ & $\begin{array}{c}0 \\
(0 \%)\end{array}$ & $\begin{array}{c}0 \\
(0 \%)\end{array}$ & 50 \\
\hline 3 & $\begin{array}{l}\text { Jenis dan ukuran font yang digunakan } \\
\text { dapat dibaca dengan jelas }\end{array}$ & $\begin{array}{c}16 \\
(32 \%)\end{array}$ & $\begin{array}{c}25 \\
(50 \%)\end{array}$ & $\begin{array}{c}9 \\
(18 \%)\end{array}$ & $\begin{array}{c}0 \\
(0 \%)\end{array}$ & $\begin{array}{c}0 \\
(0 \%)\end{array}$ & 50 \\
\hline 4 & $\begin{array}{l}\text { Menu icon dan tombol dapat dengan } \\
\text { mudah dipahami }\end{array}$ & $\begin{array}{c}17 \\
(34 \%)\end{array}$ & $\begin{array}{c}28 \\
(56 \%)\end{array}$ & $\begin{array}{c}5 \\
(10 \%)\end{array}$ & $\begin{array}{c}0 \\
(0 \%)\end{array}$ & $\begin{array}{c}0 \\
(0 \%)\end{array}$ & 50 \\
\hline 5 & $\begin{array}{l}\text { Tata letak content mudah dan nyaman } \\
\text { untuk dilihat }\end{array}$ & $\begin{array}{c}18 \\
(36 \%)\end{array}$ & $\begin{array}{c}27 \\
(54 \%)\end{array}$ & $\begin{array}{c}5 \\
(10 \%)\end{array}$ & $\begin{array}{c}0 \\
(0 \%)\end{array}$ & $\begin{array}{c}0 \\
(0 \%)\end{array}$ & 50 \\
\hline
\end{tabular}

Tabel 1 menunjukan analisa hasil pengujian terhadap aspek tampilan antar muka sistem yang dilakukan kepada 50 orang responden dengan subjek dalam pengujian sistem ditujukan kepada User sebagai pengguna jasa dan User sebagai penyedia jasa (pihak studio). Pengujian pada aspek ini bertujuan untuk memberi penilaian tampilan antar muka sistem berdasarkan variabel pengujian. Setiap variabel pengujian terdapat jumlah dan persentase responden yang menjawab sangat setuju, setuju, netral, tidak setuju, dan sangat tidak setuju yang terkait penilaian tampilan antar muka sistem. Hasil pengujian dari kelima variable pada aspek tampilan antar muka sistem memperoleh persentase rata-rata jawaban yang dibulatkan yaitu sangat setuju 
sebanyak $37 \%$, setuju sebanyak $52 \%$, dan netral sebanyak $11 \%$.

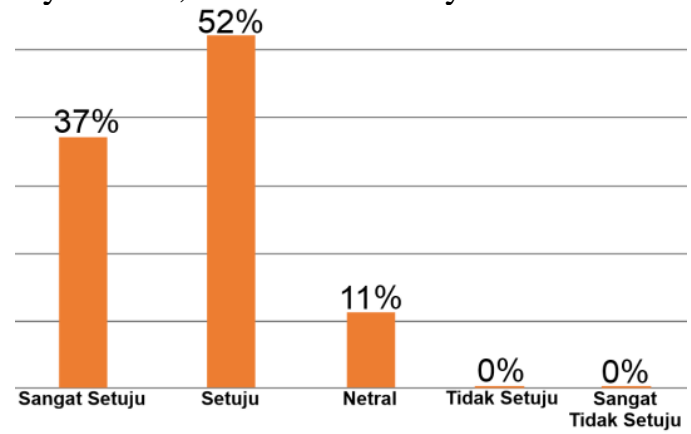

Gambar 13 Diagram Rata-rata Persentase Hasil Pengujian Tampilan Antar Muka Sistem

Gambar 13 menampilkan diagram batang dari rata-rata persentase hasil pengujian tampilan antar muka sistem yang dilakukan terhadap 50 responden dengan subjek dalam pengujian sistem ditujukan kepada User sebagai pengguna jasa dan User sebagai penyedia jasa (pihak studio). Diagram menunjukan persentase tertinggi yaitu menjawab setuju dengan nilai $52 \%$. Selain pengujian terhadap tampilan antar muka sistem, berikut merupakan hasil uji coba terhadap kinerja proses dan fitur sistem pada Tabel 2.

Tabel 2 Analisa Hasil Pengujian Kinerja Proses dan Fitur Sistem

\begin{tabular}{|c|c|c|c|c|c|c|c|}
\hline NO & Variabel Pengujian & $\begin{array}{l}\text { Sangat } \\
\text { Setuju }\end{array}$ & Setuju & Netral & $\begin{array}{l}\text { Tidak } \\
\text { Setuju }\end{array}$ & $\begin{array}{l}\text { Sangat } \\
\text { Tidak } \\
\text { Setuju }\end{array}$ & $\begin{array}{c}\text { Jumlah } \\
\text { Responden }\end{array}$ \\
\hline 1 & $\begin{array}{l}\text { Website marketplace ini dapat berjalan } \\
\text { dengan baik pada web browser Google } \\
\text { Chrome }\end{array}$ & $\begin{array}{c}20 \\
(40 \%)\end{array}$ & $\begin{array}{c}29 \\
(58 \%)\end{array}$ & $\begin{array}{c}1 \\
(2 \%)\end{array}$ & $\begin{array}{c}0 \\
(0 \%)\end{array}$ & $\begin{array}{c}0 \\
(0 \%)\end{array}$ & 50 \\
\hline 2 & $\begin{array}{l}\text { Fungsi dan tombol dapat digunakan dan } \\
\text { berjalan dengan baik }\end{array}$ & $\begin{array}{c}19 \\
(38 \%)\end{array}$ & $\begin{array}{c}25 \\
(50 \%)\end{array}$ & $\begin{array}{c}6 \\
(12 \%)\end{array}$ & $\begin{array}{c}0 \\
(0 \%)\end{array}$ & $\begin{array}{c}0 \\
(0 \%)\end{array}$ & 50 \\
\hline 3 & $\begin{array}{l}\text { Sistem ini mudah untuk dipahami dan } \\
\text { digunakan }\end{array}$ & $\begin{array}{c}18 \\
(36 \%)\end{array}$ & $\begin{array}{c}25 \\
(50 \%)\end{array}$ & $\begin{array}{c}7 \\
(14 \%)\end{array}$ & $\begin{array}{c}0 \\
(0 \%)\end{array}$ & $\begin{array}{c}0 \\
(0 \%)\end{array}$ & 50 \\
\hline 4 & $\begin{array}{l}\text { Terbantu untuk mencari jasa dengan } \\
\text { sesuai keinginan User }\end{array}$ & $\begin{array}{c}28 \\
(56 \%) \\
\end{array}$ & $\begin{array}{c}19 \\
(38 \%) \\
\end{array}$ & $\begin{array}{c}3 \\
(6 \%) \\
\end{array}$ & $\begin{array}{c}0 \\
(0 \%)\end{array}$ & $\begin{array}{c}0 \\
(0 \%)\end{array}$ & 50 \\
\hline 5 & $\begin{array}{l}\text { Terbantu untuk melakukan pemesanan } \\
\text { jasa }\end{array}$ & $\begin{array}{c}25 \\
(50 \%)\end{array}$ & $\begin{array}{c}24 \\
(48 \%)\end{array}$ & $\begin{array}{c}1 \\
(2 \%)\end{array}$ & $\begin{array}{c}0 \\
(0 \%)\end{array}$ & $\begin{array}{c}0 \\
(0 \%)\end{array}$ & 50 \\
\hline 6 & $\begin{array}{l}\text { Terbantu untuk berkomunikasi dengan } \\
\text { fitur Chat }\end{array}$ & $\begin{array}{c}21 \\
(42 \%)\end{array}$ & $\begin{array}{c}25 \\
(50 \%) \\
\end{array}$ & $\begin{array}{c}4 \\
(8 \%)\end{array}$ & $\begin{array}{c}0 \\
(0 \%)\end{array}$ & $\begin{array}{c}0 \\
(0 \%)\end{array}$ & 50 \\
\hline 7 & $\begin{array}{l}\text { Terbantu untuk memperoleh hasil dari } \\
\text { dokumentasi }\end{array}$ & $\begin{array}{c}31 \\
(62 \%)\end{array}$ & $\begin{array}{c}17 \\
(34 \%)\end{array}$ & $\begin{array}{c}2 \\
(4 \%)\end{array}$ & $\begin{array}{c}0 \\
(0 \%)\end{array}$ & $\begin{array}{c}0 \\
(0 \%)\end{array}$ & 50 \\
\hline 8 & $\begin{array}{l}\text { Terbantu untuk mengelola jasa yang } \\
\text { dimiliki }\end{array}$ & $\begin{array}{c}13 \\
(26 \%)\end{array}$ & $\begin{array}{c}28 \\
(56 \%)\end{array}$ & $\begin{array}{c}9 \\
(18 \%)\end{array}$ & $\begin{array}{c}0 \\
(0 \%)\end{array}$ & $\begin{array}{c}0 \\
(0 \%)\end{array}$ & 50 \\
\hline 9 & Terbantu untuk mengelola jadwal studio & $\begin{array}{c}23 \\
(46 \%)\end{array}$ & $\begin{array}{c}24 \\
(48 \%)\end{array}$ & $\begin{array}{c}3 \\
(6 \%) \\
\end{array}$ & $\begin{array}{c}0 \\
(0 \%)\end{array}$ & $\begin{array}{c}0 \\
(0 \%) \\
\end{array}$ & 50 \\
\hline 10 & Terbantu untuk mengelola pemesanan & $\begin{array}{c}21 \\
(42 \%)\end{array}$ & $\begin{array}{c}28 \\
(56 \%)\end{array}$ & $\begin{array}{c}1 \\
(2 \%)\end{array}$ & $\begin{array}{c}0 \\
(0 \%)\end{array}$ & $\begin{array}{c}0 \\
(0 \%)\end{array}$ & 50 \\
\hline 11 & $\begin{array}{l}\text { Terbantu untuk mengelola hasil } \\
\text { dokumentasi }\end{array}$ & $\begin{array}{c}19 \\
(28 \%)\end{array}$ & $\begin{array}{c}25 \\
(50 \%)\end{array}$ & $\begin{array}{c}6 \\
(12 \%)\end{array}$ & $\begin{array}{c}0 \\
(0 \%)\end{array}$ & $\begin{array}{c}0 \\
(0 \%)\end{array}$ & 50 \\
\hline 12 & $\begin{array}{l}\text { Tertarik kembali untuk menggunakan } \\
\text { sistem ini }\end{array}$ & $\begin{array}{c}22 \\
(44 \%)\end{array}$ & $\begin{array}{c}22 \\
(44 \%)\end{array}$ & $\begin{array}{c}6 \\
(12 \%)\end{array}$ & $\begin{array}{c}0 \\
(0 \%)\end{array}$ & $\begin{array}{c}0 \\
(0 \%)\end{array}$ & 50 \\
\hline 13 & $\begin{array}{l}\text { Puas dengan fitur dan proses yang } \\
\text { disediakan pada system }\end{array}$ & $\begin{array}{c}24 \\
(48 \%) \\
\end{array}$ & $\begin{array}{c}20 \\
(40 \%) \\
\end{array}$ & $\begin{array}{c}6 \\
(12 \%) \\
\end{array}$ & $\begin{array}{c}0 \\
(0 \%)\end{array}$ & $\begin{array}{c}0 \\
(0 \%) \\
\end{array}$ & 50 \\
\hline \multicolumn{2}{|r|}{ Rata-rata } & $43 \%$ & $48 \%$ & $9 \%$ & $0 \%$ & $0 \%$ & \\
\hline
\end{tabular}

Tabel 2 menunjukan analisa hasil pengujian terhadap aspek kinerja proses dan fitur sistem yang dilakukan kepada 50 orang responden dengan subjek dalam pengujian sistem ditujukan kepada User sebagai pengguna jasa dan User sebagai penyedia jasa (pihak studio). Pengujian pada aspek ini bertujuan untuk mengetahui tingkat kepuasan pengguna setelah implementasi terkait pemecahan masalah yang telah disebutkan pada Pendahuluan. Selain itu pengujian sistem juga bertujuan khususnya untuk mengetahui tingkat kemanfaatan dari dua (2) fitur baru yang tersedia yaitu fitur pengelolaan hasil dokumentasi dan jadwal kerja dengan meggunakan variable pengujian nomor 7 dan 9 pada Tabel 2. Hasil pengujian dari 13 variable pada aspek kinerja proses dan fitur sistem memperoleh persentase rata-rata jawaban yang 
dibulatkan yaitu sangat setuju sebanyak 43\%, setuju sebanyak 48\%, dan netral sebanyak 9\%. Sedangkan rata-rata persentase hasil pengujian 2 fitur baru dengan menggunakan variable pengujian nomor 7 dan 9 yaitu respoden yang menjawab sangat setuju sebanyak $54 \%$, setuju sebanyak $41 \%$, dan netral sebanyak $5 \%$ merasa tebantu dengan adanya 2 fitur tersebut.

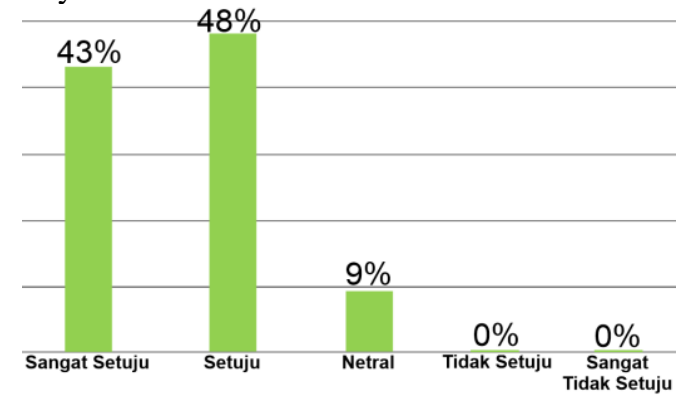

Gambar 14 Diagram Rata-rata Persentase Hasil Pengujian Kinerja Proses dan Fitur Sistem

Gambar 14 menampilkan diagram batang dari rata-rata persentase hasil pengujian terhadap kinerja proses dan fitur sistem yang dilakukan terhadap 50 responden dengan subjek dalam pengujian sistem ditujukan kepada User sebagai pengguna jasa dan User sebagai penyedia jasa (pihak studio). Diagram menunjukan persentase tertinggi yaitu menjawab setuju dengan nilai $48 \%$.

\section{KESIMPULAN}

Berdasarkan pembahasan diatas terdapat beberapa kesimpulan yang bisa diambil dari penelitian ini yaitu sebagai berikut.

1. Belum adanya media atau wadah bagi para pengguna maupun penyedia jasa sebagai titik temu dalam proses jual beli jasa dokumentasi. Hal tersebut yang menyebabkan penelitian ini ada. Salah satu solusi untuk memecahkan masalah tersebut yaitu membangun sistem marketplace berbasis website yang khusus menjual belikan jasa dokumentasi pernikahan.

2. Terdapat dua fitur tambahan baru dan unik yang belum ada pada penelitian-penelitian sebelumnya khususnya pada penelitian [7]. Dua fitur tambahan yaitu fitur untuk mengunggah dan mengunduh hasil dokumentasi pada website dan fitur untuk memanajemen jadwal kerja bagi penyedia jasa. Pada pengujian kinerja proses dan fitur sistem terdapat dua variabel pengujian yang terkait dua fitur tersebut yaitu variabel pengujian nomor 7 dan 9 pada Tabel 2. Pengujian sistem dilakukan terhadap 50 orang responden dengan subjek dalam pengujian sistem ditujukan kepada User sebagai pengguna jasa dan User sebagai penyedia jasa (pihak studio). Hasil dari variabel pengujian tersebut rata-rata menjawab sangat setuju sebanyak $54 \%$, setuju sebanyak $41 \%$, dan netral sebanyak 5\% yang merasa tebantu dengan adanya 2 fitur tersebut.

3. Analisa hasil pengujian sistem dilakukan bertujuan untuk mengetahui tingkat kepuasan pengguna setelah implementasi terkait pemecahan masalah yang telah disebutkan pada Pendahuluan. Analisa hasil pengujian sistem dilakukan terhadap 50 orang responden dengan subjek dalam pengujian sistem ditujukan kepada User sebagai pengguna jasa dan User sebagai penyedia jasa (pihak studio). Dengan mengujikan dua buah aspek yaitu pada aspek antar muka sistem dan pada aspek kinerja proses dan fitur sistem. Pengujian pada aspek antar muka sistem menghasilkan persentase rata-rata jawaban sangat setuju sebanyak $37 \%$, setuju sebanyak 52\%, dan netral sebanyak $11 \%$. Pengujian pada aspek kinerja proses dan fitur sistem menghasilkan persentase rata-rata jawaban sangat setuju sebanyak $43 \%$, setuju sebanyak $48 \%$, dan netral sebanyak $9 \%$. Maka dari analisa hasil pengujian dari dua buah aspek menunjukan bahwa sistem dapat digunakan sesuai dengan fungsinya. 


\section{DAFTAR PUSTAKA}

[1] S. Hidayati, "Penyesuaian Budaya dalam Perkawinan," Journal of Multicultural Studies in Guidance and Counseling, vol. 1, no. 1, pp. 83-98, 2017.

[2] N. Nelly and S. J. K. Azeharie, "Foto Prewedding Sebagai Bagian dari Gaya Hidup," Jurnal Koneksi Untar, vol. 2, no. 1, pp. 132-135, 2018.

[3] C. I. P. Nindhia and I. N. A. F. J. J. B. R. Setiawan, "ESTETIKA IDEATIONAL FOTO PREWEDDING STYLE BALI," Jurnal Bahasa Rupa, vol. 3, no. 1, pp. 42-47, 2019.

[4] O. B. J. J. M. Nasution, "Faktor Penentu Sikap Konsumen untuk Berbelanja Daring melalui Marketplace," Jurnal Manajemen, vol. 9, no. 1, pp. 206-214, 2019.

[5] A. Farki, "Pengaruh online customer review dan rating terhadap kepercayaan dan minat pembelian pada online marketplace di Indonesia," Institut Teknology Sepuluh Nopember, 2016.

[6] D. Apriadi and A. Y. J. J. R. Saputra, "E-Commerce Berbasis Marketplace Dalam Upaya Mempersingkat Distribusi Penjualan Hasil Pertanian," Jurnal RESTI, vol. 1, no. 2, pp. 131-136, 2017.

[7] D. Permata, E. Tasrif, and I. P. J. J. V. T. E. d. I. Dewi, "PERANCANGAN SISTEM INFORMASI PEMESANAN WEDDING ORGANIZER DI KOTA PADANG," Jurnal Vokasional Teknik Elektronika dan Informatika, vol. 6, no. 1, 2018.

[8] R. Imam and A. R. J. J. M. d. T. I. Nugraha, "PERANCANGAN SISTEM INFORMASI E-MARKETPLACE ORIGINAL CLOTHING INDONESIA BERBASIS WEB," Jurnal Manajemen dan Teknik Informatika, vol. 1, no. 1, 2018.

[9] A. K. Putra, R. D. Nyoto, and H. S. J. J. S. d. T. I. Pratiwi, "Rancang Bangun Aplikasi Marketplace penyedia jasa les private di kota Pontianak Berbasis Web," Jurnal Sistem dan Teknologi Informasi, vol. 5, no. 1, pp. 22-26, 2017.

[10] R. S. Pressman, Software engineering: a practitioner's approach. Palgrave macmillan, 2005. 